\title{
Safety and Tolerability of Donepezil, Rivastigmine and Galantamine for Patients with Alzheimer's Disease: Systematic Review of the 'Real-World' Evidence
}

\author{
I.A. Lockhart ${ }^{\text {a }}$ S.A. Mitchell ${ }^{\text {b }}$ S. Kelly ${ }^{\mathrm{a}}$ \\ a Pfizer Ltd., Walton-On-The-Hill, and ${ }^{b}$ Abacus International, Bicester, UK
}

\section{Key Words}

Alzheimer's disease $\cdot$ Cholinesterase inhibitors .

Real-world setting

\begin{abstract}
Background/Aims: The purpose of this systematic review was to compare the safety and tolerability of the cholinesterase inhibitors (ChEls) donepezil, rivastigmine and galantamine for treating mild to moderate Alzheimer's disease (AD) patients in routine clinical practice. Methods: Electronic databases (Cochrane Library, Medline, EMBASE; accessed October 2008) and manual bibliographic searches were conducted to identify head-to-head non-randomised studies examining ChEls for the treatment of AD. Data were extracted by 2 independent reviewers. Results: Twelve headto-head studies comparing ChEls met the pre-specified inclusion criteria; 6 retrospective analyses and 6 prospective cohort studies. Donepezil was the most widely studied treatment and galantamine the least widely prescribed therapy. Fewer donepezil-treated subjects withdrew due to adverse events (AEs) compared with rivastigmine and galantaminetreated subjects. The incidence of gastrointestinal (GI) AEs was lower following treatment with donepezil compared with rivastigmine and galantamine. Non-GI (CNS and cardiovascular) AEs occurred at a low frequency, and had a similar
\end{abstract}

incidence in subjects treated with the different ChEls. Conclusions: Subjects with mild to moderate AD treated in routine clinical practice with donepezil were more adherent to pharmacotherapy, and had a lower risk of GI AEs compared with rivastigmine or galantamine. This finding accords with results reported in the randomised clinical trial literature.

Copyright $\odot 2009$ S. Karger AG, Basel

\section{Introduction}

Age-related cognitive changes encompass a wide spectrum of diseases ranging from benign memory loss or age-related cognitive decline, through mild cognitive impairment, to dementia [1]. Dementia affects about 800,000 people in the UK, of which Alzheimer's disease (AD) is the most common cause $(60 \%)$, followed by vascular dementia (20\%), dementia with Lewy bodies (15\%) and rarer and reversible causes (5\%) [2]. AD manifests as a progressive, degenerative brain disorder resulting in cognitive and behavioural decline which can lead to complete psychological and physical dependency and finally to death.

Consequently, dementia is one of the most disabling and burdensome health conditions worldwide [3], and is believed to be the cause of $3 \%$ of all deaths, and a con-

\section{KARGER \\ Fax +4161306 1234 E-Mail karger@karger.ch} www.karger.com

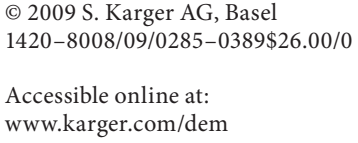

Ian Lockhart

Pfizer Ltd., Walton Oaks (IPC 2G)

Dorking Road

Walton-On-The-Hill, Surrey KT20 7NS (UK)

Tel. +44 1737330 573, Fax +44 1737330 206,E-Mail Ian.Lockhart@pfizer.com 
tributory factor in up to $13 \%$ of all deaths [4]. In England alone, the estimated annual economic burden of late-onset dementia is estimated to be GBP 14.3 billion [5].

At present, there are 2 classes of medication approved for the treatment of $\mathrm{AD}$. The cholinesterase inhibitors (ChEIs) are indicated for the treatment of mild to moderate $\mathrm{AD}$ only, and include donepezil (Aricept ${ }^{\circledR}$ ), galantamine $\left(\right.$ Reminyl $\left.^{\circledR}\right)$ and rivastigmine $\left(\right.$ Exelon $\left.^{\circledR}\right)$ [6]. The $\mathrm{N}$-methyl-D-aspartate antagonist memantine $\left(\mathrm{Ebixa}^{\circledR}\right)$ is the only treatment licensed for the treatment of moderate to severe dementia. The National Institute for Health and Clinical Excellence does not recommend memantine for people with moderately severe to severe AD in England and Wales unless it is used as part of a clinical trial (research) [6], and in Scotland it is not recommended for use in this population [7].

Results from randomised clinical trials (RCTs) have indicated that treatment with ChEIs stabilises or slows decline in cognition, function, behaviour and global change in subjects with $\mathrm{AD}[2,8-10]$. However, the majority of RCTs examining the efficacy and safety of the ChEIs have been placebo-controlled studies and, to ensure the internal validity of their findings, many RCTs exclude subjects with multiple comorbid conditions [11]. Consequently, subjects enrolled in RCTs may not be representative of $\mathrm{AD}$ patients treated in a 'real-world' setting, limiting the external validity of study results [12]. In contrast, studies performed in a naturalistic setting may include a broader range of patients more akin to those seen in clinical practice and are particularly useful for collecting real-life descriptive data on the efficacy and safety of pharmacological treatments for chronic diseases such as AD $[13,14]$.

The majority of RCTs and systematic reviews conducted to date have reported no significant differences between the ChEIs in terms of effects on cognition $[8,15-$ 18]. However, across trials, differences have been reported in the incidence of AEs (generally lowest for donepezil and highest for rivastigmine) $[8,19,20]$. Consequently, the present systematic review was conducted to review whether the difference in the incidence of AEs between ChEIs reported in the RCT literature was also reflected in the 'real-world' healthcare setting.

\section{Methods}

Electronic databases and conference proceedings were searched to identify relevant studies. Medline, EMBASE and the Cochrane Library were accessed on October 10, 2008. There were no restrictions by date of publication. The search combined both
$\mathrm{MeSH}$ and free-text terms for 'dementia' or 'Alzheimer's disease' with the interventions 'donepezil', 'rivastigmine' and 'galantamine' and publication type 'cohort', 'retrospective' or 'naturalistic' study. The focus of the database search was on head-to-head studies of donepezil compared with rivastigmine and/or galantamine only. Non-comparative observational study designs were excluded from consideration (table 1).

The following conference proceedings were hand-searched (2003-2008 inclusive): International Conference on Alzheimer's Disease, European Federation of Neurological Societies Congress, and European College of Neuropsychopharmacology Congress. Cited references from included studies and previously published reviews were also searched.

Identified studies were independently assessed by 2 reviewers in order to ascertain whether they met a set of pre-defined inclusion/exclusion criteria (table 1), and discrepancies were resolved by a third party. The primary outcome measures of the review were the incidence of overall AEs, withdrawals due to AEs and the incidence of individual AEs where reported. The mean daily dose of ChEI and number of subjects tolerating a particular dose were also recorded.

Due to potential heterogeneity in included studies (e.g. differences in study design, study duration, titration schedule, definition of individual AEs), it was decided a priori to conduct a qualitative analysis of the results rather than perform a meta-analysis via a direct or indirect comparison.

Data were extracted from eligible publications by a reviewer into an Excel ${ }^{\circledR}$ spreadsheet. A second reviewer checked the resulting extraction and any discrepancies were resolved through discussion.

\section{Quality Assessment}

It is necessary to critically examine the methodological design of head-to-head studies in order to assess the credibility and interpretation of results. Two reviewers independently assessed the methodological quality of the included observational studies using the Newcastle-Ottawa Scale (NOS) [21]. This scale is specifically designed to appraise the methodological quality of comparative cohort and case control studies. It has been partly validated, and is the scale recommended by the Cochrane Non-Randomised Studies Method Working Group [22]. The 8-item instrument consists of 3 subscales: selection of subjects (4 items), comparability of subjects ( 1 item) and assessment of outcome/exposure ( 3 items). Studies were awarded 1 point for each item they met, with a maximum of 2 points awarded for comparability of subjects. Overall study quality was defined as poor (score of $0-4)$, moderate (5-6) or good (7-9).

\section{Results}

In total, 2,599 citations were identified through electronic database searching, of which 2,498 were excluded on the basis of title and abstract (fig. 1). On re-application of the review inclusion criteria to the 101 full-text papers, a further 91 were excluded. Two additional full-text studies were identified via hand-searching. Therefore, 12 
Table 1. Inclusion and exclusion criteria

\begin{tabular}{|c|c|c|}
\hline Criterion & Included & Excluded \\
\hline Population & $\begin{array}{l}\text { age: } \geq 18 \text { years; } \\
\text { race: any; } \\
\text { qualifying disease: Alzheimer's disease (diagnosed with established } \\
\text { criteria, e.g. DSM-IV, NIHCDS-ADRDA); } \\
\text { any severity of disease at baseline; } \\
\text { community/nursing home-dwelling resident }\end{array}$ & age: $<18$ years \\
\hline Perspective of study & $\begin{array}{l}\text { prospective (concurrent); } \\
\text { retrospective (non-concurrent, historical); } \\
\text { comparative }\end{array}$ & \\
\hline Type of study & $\begin{array}{l}\text { non-randomised controlled clinical trial; } \\
\text { cohort; } \\
\text { observational; } \\
\text { case control; } \\
\text { cross-sectional; } \\
\text { head-to-head study comparing relevant intervention; } \\
\text { cross-over trials with a wash-out period between treatments }\end{array}$ & $\begin{array}{l}\text { randomised clinical trial } \\
\text { (open-label or blinded); } \\
\text { non-comparative study }\end{array}$ \\
\hline Language & all & none \\
\hline Study duration & any & none \\
\hline Sample size & any & none \\
\hline Interventions/treatments & $\begin{array}{l}\text { any ChEI licensed for the treatment of Alzheimer's disease (all doses): } \\
\text { - donepezil } \\
\text { - rivastigmine } \\
\text { - galantamine }\end{array}$ & $\begin{array}{l}\text { placebo only } \\
\text { comparative arm }\end{array}$ \\
\hline Control intervention/treatments & any of the above interventions & \\
\hline Included study outcomes & safety/tolerability & efficacy only \\
\hline
\end{tabular}

NIHCDS-ADRDA = National Institute of Neurological and Communicative Disorders and Stroke and the Alzheimer Disease and Related Disorders Association.

studies met the inclusion criteria, and were included in the systematic review [23-34].

Of the 12 relevant studies undergoing assessment for methodological quality, 1 was assessed to be of poor quality (score of 4 out of 9 on the NOS) [34] and 2 were found to be of moderate quality (range 5-6 out of 9 on the NOS) $[24,25]$. The study by Hughes et al. [25] compared nursing home residents who may be more likely to have advanced $\mathrm{AD}$ than subjects in the general population. One study [34] was only available as an abstract and therefore reported limited study details, which resulted in a score of 4 on the NOS scale. The remaining 9 studies [23, 2633 ] were judged to be of good quality (range: 7-9).

Study characteristics are detailed in table 2. Eleven studies were published in full [23-33], and 1 was available as a conference abstract [34]. Three foreign-language publications with English abstracts were translated in order to extract relevant results [23, 29-31].

Six of the studies were retrospective analyses of patient medical records [23, 24, 30, 33] or prescription databases $[25,29]$, and the remaining 6 were prospective open-label cohort studies [26-28, 31, 32, 34].

For both retrospective and prospective studies, donepezil was the most frequently prescribed ChEI, followed by rivastigmine and galantamine (table 2). Donepezil versus rivastigmine versus galantamine:

- retrospective analyses $n=6,294$ vs. 1,842 vs. 809 , respectively;

- prospective studies $n=4,034$ vs. 2,143 vs. 418 , respectively. 


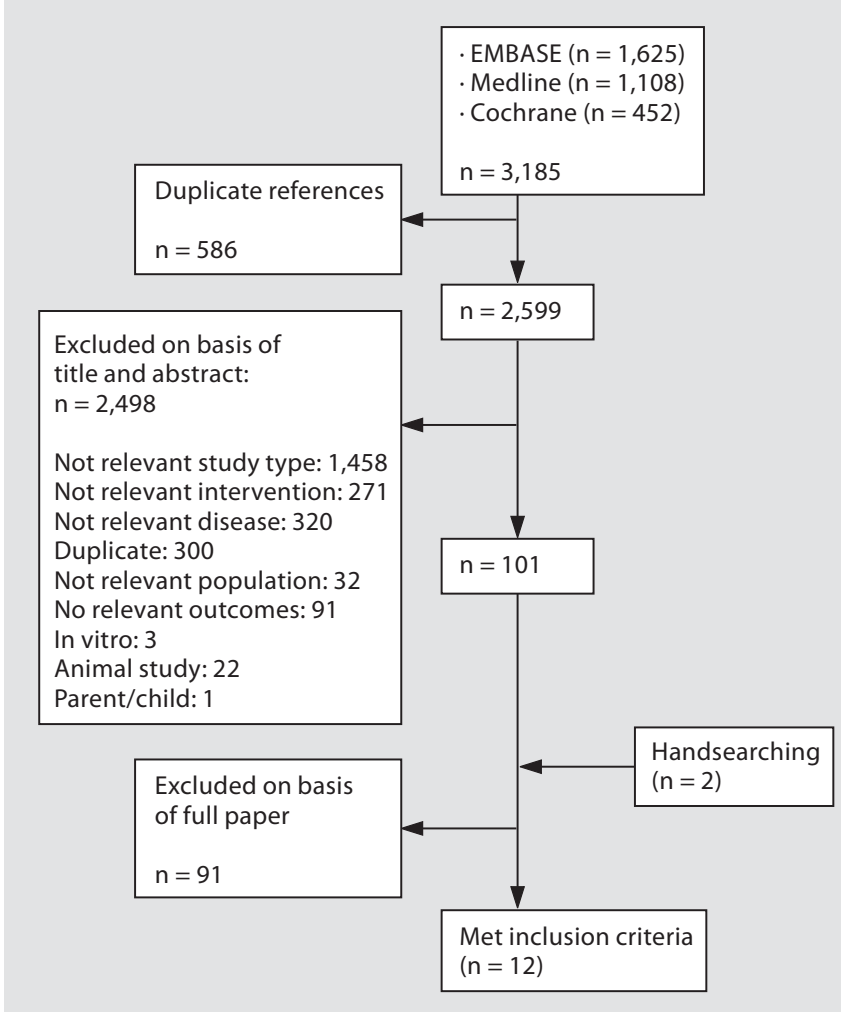

Fig. 1. Flowchart showing inclusion/exclusion process.

Two of the included studies compared donepezil and rivastigmine only $[23,24]$, while the remaining 10 reported a head-to-head comparison of all 3 ChEIs [25-34].

\section{Retrospective Study Characteristics}

Four of the six retrospective studies were based on examination of medical records from subjects with mild to moderate $\mathrm{AD}$ enrolled in specialist dementia/psychiatric units $[23,24,33]$ or geriatric centres [30] (table 2). Treatment follow-up ranged from at least 6 months $[23,24]$ to up to 3 years [33]. Hughes et al. [25] reported the incidence of gastrointestinal (GI) AEs obtained from a healthstatus questionnaire completed by nursing home residents treated with a ChEI for up to 1 year. The final study assessed the notification of AEs (all cause and treatment related) in ChEI-treated subjects reported to 4 pharmacovigilance centres in France [29].

\section{Prospective Study Characteristics}

Four of the six prospective studies reported data from the CRONOS project, a national project initiated by the
Italian government in October 2000 [26, 27, 31, 32]. The project involved 503 Alzheimer evaluation units (AEUs) and aimed to standardise ChEI prescriptions and to assess their effects on defined outcomes (cognition, functional status, behaviour) in non-selected subjects with mild to moderate $\mathrm{AD}$ [35]. No restrictions on which ChEI was prescribed were applied in 3 of the 4 studies [26, 27, 31,32 ], although galantamine only became available for treatment from April 2001 onwards. However, in the study by Aguglia et al. [31], treatment was assigned in a pseudo-randomised fashion based on arrival at the AEU following the availability of galantamine.

The study cohort investigated by Raschetti et al. [32] consisted of 5,462 treatment-naïve subjects treated at 118 of the 503 AEUs between September 2000 and December 2001. Subjects were followed until discontinuation for any reason, admission to hospital or nursing home, cognitive decline (MMSE $<10$ ) or death; 2,853 subjects completed 9 months of therapy. Mossello et al. [26] reported safety data for 407 subjects referred to 2 AEUs between September 2000 and July 2002. However, only 5\% of subjects $(n=19)$ were prescribed galantamine in this study. In the third study, results from 354 subjects evaluated at a single AEU between November 2000 and November 2002 were reported [27]. In the final study, 242 treatmentnaïve subjects referred to a single AEU were followed for 6 months [31].

The remaining 2 studies evaluated subjects with probable AD referred to primary health care centres who underwent ChEI treatment for 6 [28] or 9 months [34]. Previous treatment with a ChEI was not permitted in 1 study [34], and not reported as an exclusion criterion in the other [28].

Details of the main safety/tolerability data reported in the studies are given in tables 3-7.

\section{Frequency of Total AEs}

The incidence of total AEs was reported in 3 retrospective studies, 2 comparing donepezil with rivastigmine [23, 24] and 1 comparing all 3 ChEIs [33]. A similar incidence of AEs was reported between donepezil and rivastigmine (donepezil $43.9 \%$, range $19.5-71.3 \%$ vs. rivastigmine $48.1 \%$, range $20.1-78 \%$; table 5) [23, 24, 33]. In the single study reporting a head-to-head comparison between the 3 ChEIs, the highest incidence of all AEs was reported in galantamine-treated subjects $(5 / 9,55 \%)$ compared with $46.1 \%$ in rivastigmine- $(12 / 26)$ and $40.8 \%$ in donepezil-treated subjects (51/125) [33]. Although the study by De La Gastine et al. [29] reported the incidence of all observed AEs, the data were of limited use as the 
Table 2. Type of study, participants, details of intervention and duration of studies comparing donepezil, galantamine and rivastigmine

\begin{tabular}{|c|c|c|c|c|c|c|c|}
\hline Study & Format & Country & Type of study & Participants & Intervention & $\begin{array}{l}\text { Number } \\
\text { of subjects }\end{array}$ & Duration of study \\
\hline $\begin{array}{l}\text { Retrospective stı } \\
\text { De La Gastine } \\
\text { et al. [29] } \\
(2007)\end{array}$ & $\begin{array}{l}\text { full paper: foreign } \\
\text { language with } \\
\text { English abstract }\end{array}$ & France & $\begin{array}{l}\text { analysis of data from } \\
\text { regional pharmaco- } \\
\text { vigilance centres }\end{array}$ & subjects with $\mathrm{AD}$ & $\begin{array}{l}\text { donepezil, } \\
\text { rivastigmine, } \\
\text { galantamine, } \\
\text { memantine }\end{array}$ & $\begin{array}{l}71 \text { obser- } \\
\text { vations } \\
\text { of AEs }\end{array}$ & $\begin{array}{l}\text { observations reported } \\
\text { up to March } 2006\end{array}$ \\
\hline $\begin{array}{l}\text { Hughes } \\
\text { et al. [25] } \\
(2004)\end{array}$ & full paper & USA & $\begin{array}{l}\text { retrospective analysis of } \\
\text { Minimum Data Set }\end{array}$ & $\begin{array}{l}\text { subjects with } \mathrm{AD} \text { in } \\
\text { nursing home setting }\end{array}$ & $\begin{array}{l}\text { donepezil } \\
\text { rivastigmine } \\
\text { galantamine }\end{array}$ & $\begin{array}{r}5,845 \\
1,672 \\
750\end{array}$ & $\begin{array}{l}181 \text { days }^{2} \\
183 \text { days }^{2} \\
159 \text { days }^{2}\end{array}$ \\
\hline $\begin{array}{l}\text { Lleshi } \\
\text { et al. [30] } \\
(2004)\end{array}$ & $\begin{array}{l}\text { full paper: foreign } \\
\text { language with } \\
\text { English abstract }\end{array}$ & $\begin{array}{l}\text { Switzer- } \\
\text { land }\end{array}$ & $\begin{array}{l}\text { retrospective medical } \\
\text { record analysis }\end{array}$ & $\begin{array}{l}\text { hospital geriatric } \\
\text { population with } \mathrm{AD}\end{array}$ & $\begin{array}{l}\text { donepezil } \\
\text { rivastigmine } \\
\text { galantamine }\end{array}$ & $\begin{array}{r}48 \\
5 \\
42\end{array}$ & $\begin{array}{l}12.7 \pm 9.1 \text { months } \\
6.6 \pm 3.3 \text { months } \\
13.0 \pm 9.2 \text { months }\end{array}$ \\
\hline $\begin{array}{l}\text { Sobow and } \\
\text { Kloszewska } \\
{[24](2006)}\end{array}$ & full paper & Poland & $\begin{array}{l}\text { retrospective medical } \\
\text { record analysis }\end{array}$ & $\begin{array}{l}\text { subjects with probable/ } \\
\text { possible AD }\end{array}$ & $\begin{array}{l}\text { donepezil } \\
\text { rivastigmine }\end{array}$ & $\begin{array}{r}101 \\
82\end{array}$ & $\begin{array}{l}\text { subjects prescribed drug } \\
\text { over a period of } 3 \text { years } \\
(1998-2000) \text { and fol- } \\
\text { lowed up for } \geq 6 \text { months }\end{array}$ \\
\hline $\begin{array}{l}\text { Turon-Estrada } \\
\text { et al. [23] } \\
(2003)\end{array}$ & $\begin{array}{l}\text { full paper: foreign } \\
\text { language with } \\
\text { English abstract }\end{array}$ & Spain & $\begin{array}{l}\text { retrospective medical re- } \\
\text { cord analysis of subjects } \\
\text { enrolled in EDAC study }\end{array}$ & $\begin{array}{l}\text { subjects with very } \\
\text { slight/mild probable AD }\end{array}$ & $\begin{array}{l}\text { donepezil } \\
\text { rivastigmine }\end{array}$ & $\begin{array}{r}134 \\
41\end{array}$ & 6 months \\
\hline $\begin{array}{l}\text { Pakrasi } \\
\text { et al. [33] } \\
(2003)\end{array}$ & full paper & UK & $\begin{array}{l}\text { retrospective medical } \\
\text { record analysis }\end{array}$ & $\begin{array}{l}\text { subjects with } \mathrm{AD} \text {, } \\
\text { vascular dementia or } \\
\mathrm{DLB}\end{array}$ & $\begin{array}{l}\text { donepezil } \\
\text { rivastigmine } \\
\text { galantamine }\end{array}$ & $\begin{array}{c}125(78 \%) \\
26(16 \%) \\
9(6 \%)\end{array}$ & $\begin{array}{l}\text { analysis of data from } \\
\text { January } 1998 \text { to } \\
\text { December } 2001\end{array}$ \\
\hline $\begin{array}{l}\text { Prospective stu } \\
\text { Aguglia } \\
\text { et al. [31] } \\
(2004)\end{array}$ & $\begin{array}{l}\text { ies } \\
\text { full paper }\end{array}$ & Italy & $\begin{array}{l}\text { prospective open-label } \\
\text { study }\end{array}$ & $\begin{array}{l}\text { probable } \mathrm{AD} ; \\
\text { treatment-naïve } \\
\text { subjects }\end{array}$ & $\begin{array}{l}\text { donepezil } \\
\text { rivastigmine } \\
\text { galantamine }\end{array}$ & $\begin{array}{r}70 \\
121 \\
51\end{array}$ & 6 months \\
\hline $\begin{array}{l}\text { Fuschillo } \\
\text { et al. [27] } \\
(2004)\end{array}$ & full paper & Italy & $\begin{array}{l}\text { prospective observational } \\
\text { study }{ }^{4}\end{array}$ & $\begin{array}{l}\text { subjects with mild to } \\
\text { moderate } \mathrm{AD}\end{array}$ & $\begin{array}{l}\text { donepezil } \\
\text { rivastigmine } \\
\text { galantamine }\end{array}$ & $\begin{array}{l}52.2 \% \text { of subjects } \\
28.3 \% \text { of subjects } \\
19.6 \% \text { of subjects }\end{array}$ & 21 months \\
\hline $\begin{array}{l}\text { López-Pousa } \\
\text { et al. [28] } \\
(2005)\end{array}$ & full paper & Spain & $\begin{array}{l}\text { prospective open-label } \\
\text { study (EDAC study) }\end{array}$ & $\begin{array}{l}\text { subjects with probable, } \\
\text { mild to moderate AD }\end{array}$ & $\begin{array}{l}\text { donepezil } \\
\text { rivastigmine } \\
\text { galantamine } \\
\text { no } \mathrm{ChEI}^{6}\end{array}$ & $\begin{array}{l}40 \\
30 \\
32 \\
45\end{array}$ & 6 months \\
\hline $\begin{array}{l}\text { Mossello } \\
\text { et al. [26] } \\
(2004)\end{array}$ & full paper & Italy & $\begin{array}{l}\text { prospective open-label } \\
\text { study }\end{array}$ & $\begin{array}{l}\text { outpatient subjects with } \\
\text { mild to moderate AD }\end{array}$ & $\begin{array}{l}\text { donepezil } \\
\text { rivastigmine } \\
\text { galantamine }\end{array}$ & $\begin{array}{r}256 \\
132 \\
19\end{array}$ & 9 months \\
\hline $\begin{array}{l}\text { Raschetti } \\
\text { et al. [32] } \\
(2005)\end{array}$ & full paper & Italy & $\begin{array}{l}\text { prospective open-label } \\
\text { study }\end{array}$ & $\begin{array}{l}\text { subjects with probable, } \\
\text { mild to moderate AD }\end{array}$ & $\begin{array}{l}\text { donepezil } \\
\text { rivastigmine } \\
\text { galantamine }\end{array}$ & $\begin{array}{r}3,475 \\
1,749 \\
238\end{array}$ & 9 months \\
\hline $\begin{array}{l}\text { Shua-Haim } \\
\text { et al. [34] } \\
(2004)\end{array}$ & abstract & USA & $\begin{array}{l}\text { prospective open-label, } \\
\text { clinical study }\end{array}$ & $\begin{array}{l}\text { possible } \mathrm{AD} \text {; treatment- } \\
\text { naïve subjects }\end{array}$ & $\begin{array}{l}\text { donepezil } \\
\text { rivastigmine } \\
\text { galantamine }\end{array}$ & $\begin{array}{r}8 \\
11 \\
9\end{array}$ & 9 months \\
\hline
\end{tabular}

DLB = Dementia with Lewy Bodies; EDAC = Evolution of Alzheimer's Disease Patients and Caregivers Study.

${ }^{1}$ A nursing-home resident questionnaire used to collect information on the health status of residents. It includes information on health conditions, physical functioning, mood and behavioural patterns, oral/nutritional status, and special treatments and procedures. ${ }^{2}$ Mean study period (time frame between treatment initiation and the last Minimum Data Set assessment). ${ }^{3}$ Study examined subjects referred to specialist cognitive deficit unit (Unit of Evaluation for Alzheimer; UVA). Until galantamine became available, the treatment (donepezil or rivastigmine) was chosen by the clinician. Subsequently it was assigned pseudo-randomly based on subjects' order of arrival at the UVA, in the sequence: donepezil, rivastigmine, galantamine. ${ }^{4}$ Study examined subjects referred to specialist cognitive deficit unit (UVA). ${ }^{5} 66 / 354$ subjects met the inclusion criteria and were enrolled. ${ }^{6}$ Historical control group: subjects diagnosed with AD between 1991 and 1996 that had not received treatment with ChEIs and had neuropsychological assessments with MMSE at 6 months. 
Table 3. Withdrawal due to GI AEs reported in retrospective and prospective observational ChEIs studies

\begin{tabular}{|c|c|c|c|c|}
\hline & \multirow[t]{2}{*}{ Treatment } & \multicolumn{3}{|c|}{ Withdrawal due to } \\
\hline & & any GI AEs & nausea & vomiting \\
\hline \multicolumn{5}{|c|}{ Retrospective studies } \\
\hline \multirow{3}{*}{$\begin{array}{l}\text { Pakrasi } \\
\text { et al. [33] } \\
(2003)\end{array}$} & donepezil & & \multicolumn{2}{|l|}{$4 / 125(3.2)$} \\
\hline & rivastigmine & & \multicolumn{2}{|l|}{$4 / 26(15.4)^{*}$} \\
\hline & galantamine & & \multicolumn{2}{|l|}{$0 / 9$} \\
\hline Sobow and & donepezil & $4 / 101(4.0)$ & $0 / 101$ & $2 / 101(2 \%)$ \\
\hline Kloszewska & rivastigmine & $6 / 82(7.3)$ & $1 / 82(1.2)$ & $5 / 82$ \\
\hline [24] (2006) & & & & $(6.1)$ \\
\hline
\end{tabular}

Prospective studies

Mossello donepezil 3/256 (1.2)

et al. [26] rivastigmine 15/132 (11.4)

(2004) galantamine $3 / 19(15.8)$

Data in parentheses are percentages. ${ }^{*} \mathrm{p}<0.05$ in favour of donepezil.

numbers of subjects treated with each ChEI were not reported. Therefore, it was not possible to calculate the proportion of AEs observed for the individual ChEIs. However, the proportion of reported AEs that were thought to be treatment related could be imputed: $12 / 41(29.3 \%)$ for donepezil, 5/16 (31.3\%) for rivastigmine and $4 / 8$ (50\%) for galantamine.

A single prospective cohort study enrolling approximately 5,000 subjects [32] with probable mild to moderate $\mathrm{AD}$ reported the incidence of total $\mathrm{AEs}$, which was reported to be significantly higher $(\mathrm{p}<0.001)$ in rivastigmine- $(306 / 1,278,23.9 \%)$ or galantamine-treated subjects (52/163, 31.9\%) compared with donepezil $(425 / 2,809$, $15.1 \%)$. This difference was primarily a result of a higher incidence of GI AEs [donepezil (6\%) vs. rivastigmine (14\%) vs. galantamine $(24 \%)]$.

\section{Withdrawals due to AEs}

Three retrospective studies reported the incidence of withdrawals due to AEs [24, 30, 33] (tables 3, 4). While 1 study [24] reported a numerically lower non-significant withdrawal rate due to AEs between donepezil (14.6\%) and rivastigmine (22.8\%), a second study [33] found a statistically significant higher proportion of withdrawals due to nausea in rivastigmine compared with donepeziltreated subjects (table 3: 15.4 vs. $3.2 \%$, respectively; $\mathrm{p}=$ $0.03)$. A third study reported numerically more withdrawals in donepezil compared with galantamine-treat- ed subjects (10 vs. $2 \%)$, but the difference was not statistically significant $(\mathrm{p}=0.06)$ [30]. This study only included 5 rivastigmine-treated subjects, limiting the usefulness of any comparison with the other ChEIs (table 4).

Relevant data were reported in 2 prospective studies $[26,28]$ : one 6 -month study reported a numerically lower incidence of AE-related withdrawals in donepezil-treated subjects $(2.5 \%)$ compared with rivastigmine $(3.3 \%)$ and galantamine-treated subjects $(6.3 \%)$ [28], while a second 9-month study reported a significantly lower number of withdrawals following treatment with donepezil (3\%) compared with both rivastigmine (17\%) and galantamine $(21 \%, \mathrm{p}<0.01)$ [26]. The latter difference resulted from a higher incidence of withdrawals due to GI AEs, which occurred in $1.2 \%$ of donepezil-, $11.4 \%$ of rivastigmine-, and $15.8 \%$ of galantamine-treated subjects (table 3 ).

A head-to-head comparison of the incidence of total or individual GI AEs (nausea, vomiting, diarrhoea) was reported in 8 studies (table 5) [23-25, 27, 31-34].

\section{Gastrointestinal AEs}

The incidence of total GI AEs were reported in 2 retrospective studies [23, 24], while 3 studies reported the incidence of individual GI AEs (nausea, vomiting, diarrhoea, abdominal cramps) $[24,25,33]$. Considering total GI AEs, these were reported more frequently in rivastigmine-compared with donepezil-treated subjects (table 5: rivastigmine $26.4 \%$, range $17.1-39.0 \%$, vs. donepezil $13.1 \%$, range $4.5-23.8 \%$, respectively) $[23,24]$. The difference reached statistical significance $(\mathrm{p}=0.013)$ in 1 study, rivastigmine-treated subjects over 4 times more likely to experience a GI AE compared with donepezil-treated subjects (RR 4.39, 95\% CI 1.38-13.92) [23]. The level of nausea in galantamine-treated subjects was reported to be similar to donepezil $(\sim 11 \%)$ and lower compared to rivastigmine (20.7-23.1\%) [24, 33]. However, following treatment with galantamine, subjects were significantly more likely $(\mathrm{p}=0.035)$ to report diarrhoea $(8.9 \%)$ compared with both donepezil (6.4\%) and rivastigmine (6.8\%) [25]. No differences between ChEIs were reported for vomiting [24, 25], constipation [24] or abdominal cramps [25] (table 5).

Two prospective studies reported the incidence of total GI AEs [31, 32], while the incidence of individual GI AEs was reported in 3 studies [27, 31, 34] (table 5). Total GI AEs were reported at a similar incidence across the 3 treatment groups in 1 study [31], but occurred in more galantamine- (24\%) and rivastigmine-treated subjects (14\%) compared with donepezil in a second study (6\%) [32]. Considering individual GI AEs (table 5), the report- 
ed incidences of nausea and vomiting were comparable between ChEIs in 1 study [31], but numerically higher in rivastigmine- (nausea $14 \%$ and vomiting $10 \%$ ) and galantamine-treated subjects (12 and $8 \%$, respectively) compared with donepezil ( 7 and $6 \%$, respectively) in a second study [27]. Both studies reported a numerically higher incidence of diarrhoea in rivastigmine- (2.4-10\%) and galantamine-treated subjects (5.8-8\%) compared with donepezil $(0-5 \%)[27,31]$. The study by Shua-Haim et al. [34] enrolled only a small number of subjects $(n=29)$, and nausea was reported in a single rivastigmine-treated subject. The incidence of abdominal pain was reported in a single study, and was higher in rivastigmine and galantamine-treated subjects ( 9 and $7 \%$, respectively) compared with donepezil-treated subjects (4\%) [27].

\section{Other AEs}

Although the incidences of cardiovascular and CNSrelated AEs were reported in 5 prospective studies, these AEs occurred in a minority of subjects and there were very few statistically significant differences reported between the 3 ChEIs (tables 6, 7) [23-25, 29, 33]. One study reported that galantamine-treated subjects were significantly $(15.6 \% ; \mathrm{p}<0.01)$ less likely to lose weight compared with either rivastigmine- $(20.0 \%)$ or donepezil-treated (20.3\%) subjects [25].

Cardiovascular and CNS-related AEs were reported in 3 retrospective studies [27, 31,34]. As for the prospective studies, both cardiovascular and CNS-related AEs were reported in a low number of subjects, and there were no statistically significant differences reported between the ChEIs (tables 6, 7).

\section{Maximum Tolerated Dose Proportions}

Two retrospective studies reported the number of subjects reaching a maximum tolerated dose $[23,24]$. Fewer rivastigmine-treated subjects (4.9-21\%) received a daily dose of $12 \mathrm{mg} /$ day compared with donepezil-treated subjects who tolerated a dose of $10 \mathrm{mg} /$ day $(47-60 \%)$, with the difference reaching statistical significance $(\mathrm{p}<0.001)$ in 1 study [24].

A single prospective study reported relevant data [28]. At 6 months, $82.5 \%$ of donepezil subjects were treated with $5 \mathrm{mg} /$ day, compared with $83.4 \%$ of rivastigminetreated subjects receiving $\geq 6 \mathrm{mg} /$ day and $65.7 \%$ of galantamine subjects treated with $\geq 16 \mathrm{mg} /$ day.

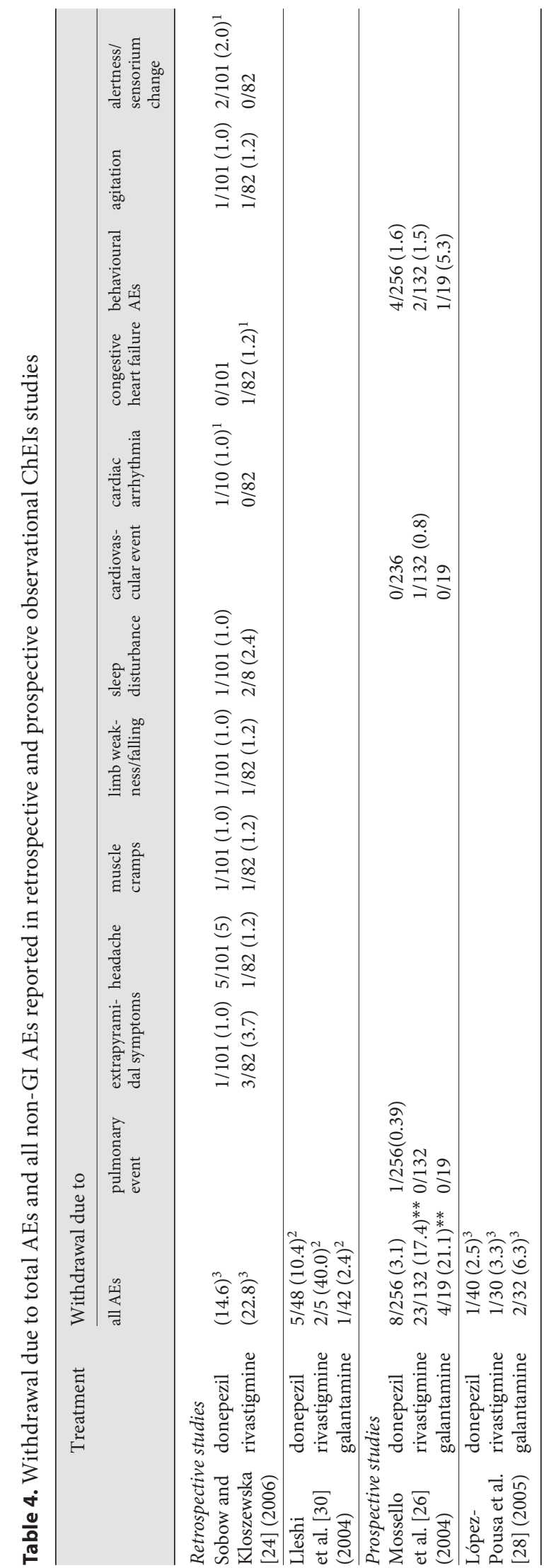




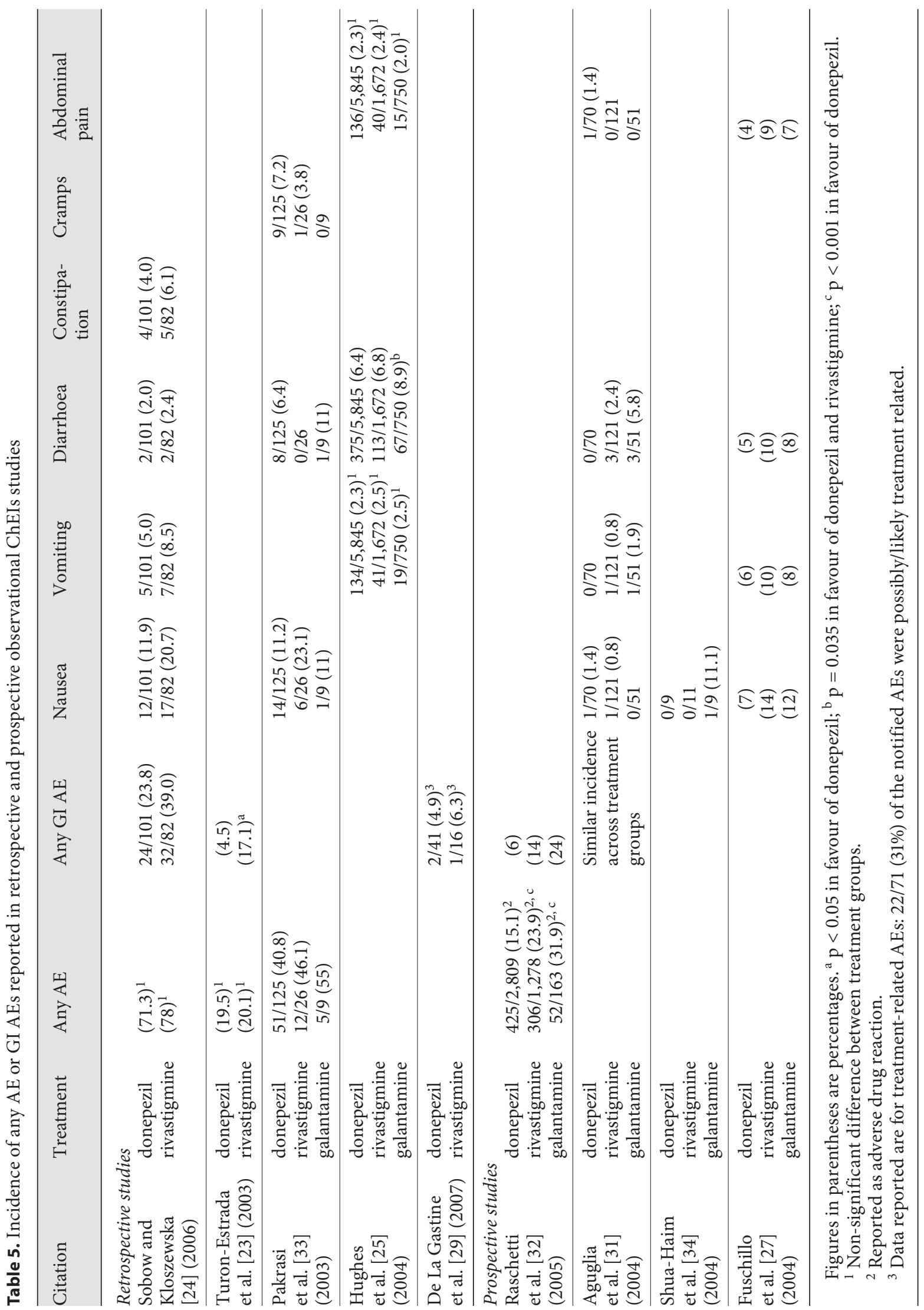




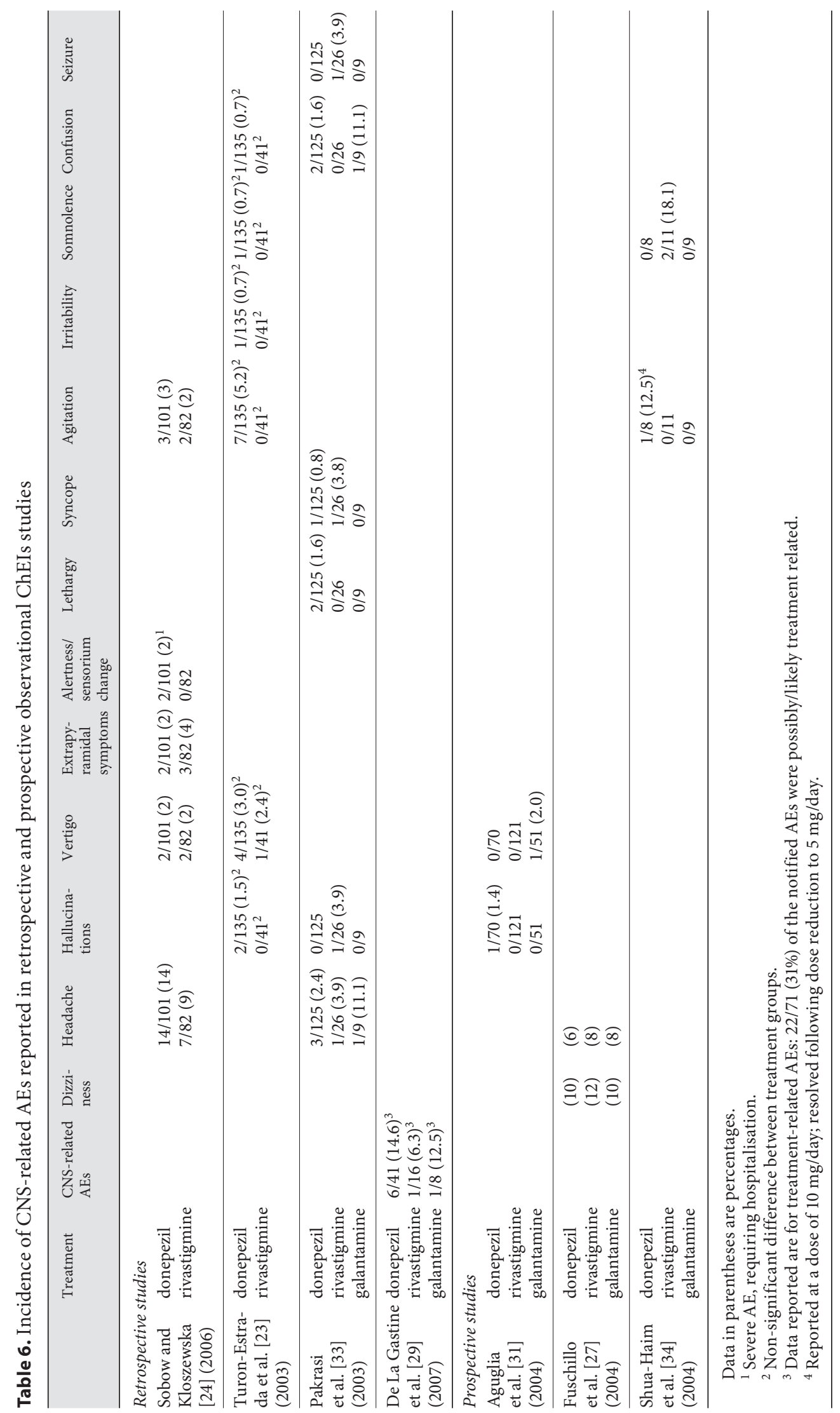




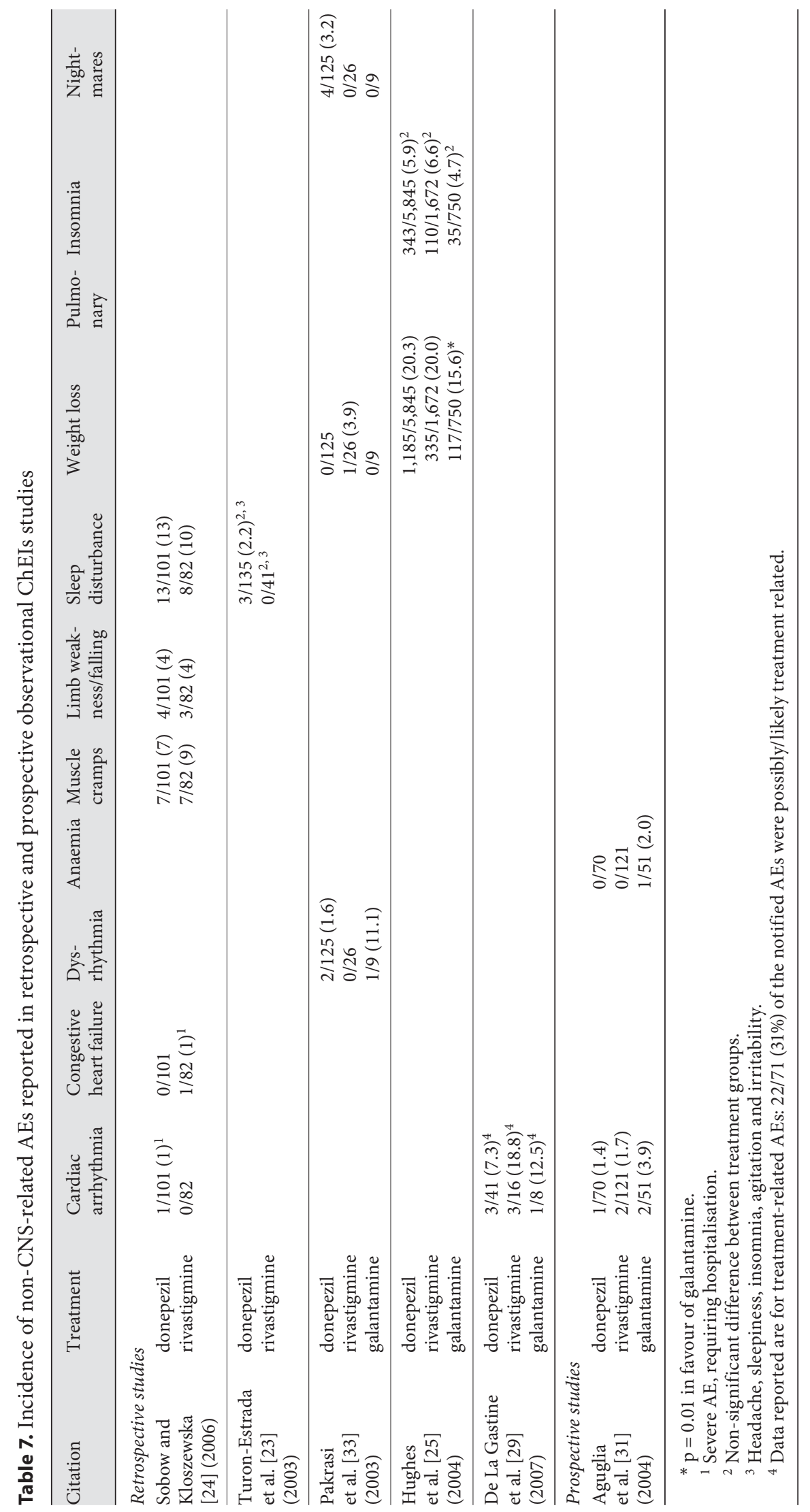


Table 8. Details of mean daily dose of ChEI administered during treatment and subjects achieving maximum dose

\begin{tabular}{|c|c|c|c|c|c|c|}
\hline Citation & Treatment & $\begin{array}{l}\text { Daily dose } \\
\text { (mean } \pm \mathrm{SD}) \\
\text { mg/day }\end{array}$ & $\begin{array}{l}\text { Reaching } \\
\text { max. dose } \\
\% \text { (mg/day) }\end{array}$ & $\begin{array}{l}\text { Clinical } \\
\text { non-tolerance } \\
\text { rate }^{1}, \%\end{array}$ & $\begin{array}{l}\text { Subjects } \\
\text { tolerating } \\
\text { low dose }{ }^{13}, \%\end{array}$ & $\begin{array}{l}\text { Subjects } \\
\text { tolerating } \\
\text { high dose } \mathrm{e}^{14}, \%\end{array}$ \\
\hline $\begin{array}{l}\text { Retrospective studies } \\
\text { Sobow and } \\
\text { Kloszewska } \\
{[24](2006)}\end{array}$ & $\begin{array}{l}\text { donepezil } \\
\text { rivastigmine }\end{array}$ & $\begin{array}{l}5-10^{2} \\
6-12^{2}\end{array}$ & $\begin{array}{l}60(10) \\
21(12)^{*}\end{array}$ & $\begin{array}{l}11.9^{5} \\
14.6^{5}\end{array}$ & $\begin{array}{l}87^{5} \\
85^{5}\end{array}$ & $\begin{array}{l}60^{5} \\
58^{5}\end{array}$ \\
\hline $\begin{array}{l}\text { Turon-Estrada } \\
\text { et al. [23] (2003) }\end{array}$ & $\begin{array}{l}\text { donepezil } \\
\text { rivastigmine }\end{array}$ & $\begin{array}{l}7.50 \pm 2.51 \\
8.40 \pm 1.40\end{array}$ & $\begin{array}{l}47(10) \\
63.4(9) \\
4.9(12)\end{array}$ & & & \\
\hline $\begin{array}{l}\text { Pakrasi } \\
\text { et al. [33] } \\
(2003)\end{array}$ & $\begin{array}{l}\text { donepezil } \\
\text { rivastigmine } \\
\text { galantamine }\end{array}$ & $\begin{array}{l}\mathrm{NR}^{3} \\
\mathrm{NR}^{3} \\
\mathrm{NR}^{3}\end{array}$ & & & & \\
\hline $\begin{array}{l}\text { Hughes } \\
\text { et al. [25] } \\
(2004)\end{array}$ & $\begin{array}{l}\text { donepezil } \\
\text { rivastigmine } \\
\text { galantamine }\end{array}$ & $\begin{array}{l}7.5^{6} \\
6.0^{6} \\
8.0^{6}\end{array}$ & & & & \\
\hline $\begin{array}{l}\text { Prospective studies } \\
\text { Aguglia } \\
\text { et al. [31] } \\
(2004)\end{array}$ & $\begin{array}{l}\text { donepezil } \\
\text { rivastigmine } \\
\text { galantamine }\end{array}$ & $\begin{array}{l}\leq 10^{10} \\
\leq 12^{11} \\
\leq 12^{12}\end{array}$ & & & & \\
\hline $\begin{array}{l}\text { Mossello } \\
\text { et al. [26] } \\
(2004)\end{array}$ & $\begin{array}{l}\text { donepezil } \\
\text { rivastigmine } \\
\text { galantamine }\end{array}$ & $\begin{array}{r}5-10 \\
6-12 \\
16-24 \\
\end{array}$ & & & & \\
\hline $\begin{array}{l}\text { López-Pousa } \\
\text { et al. [28] } \\
(2005)\end{array}$ & $\begin{array}{l}\text { donepezil } \\
\text { rivastigmine } \\
\text { galantamine }\end{array}$ & $\begin{array}{r}5.87 \pm 1.92^{7} \\
6.41 \pm 1.82^{8} \\
14.81 \pm 6.25^{9}\end{array}$ & $\begin{array}{l}82.5(5) \\
83.4(\geq 6) \\
65.7(\geq 16)\end{array}$ & & & \\
\hline $\begin{array}{l}\text { Shua-Haim } \\
\text { et al. [34] } \\
(2004)\end{array}$ & $\begin{array}{l}\text { donepezil } \\
\text { rivastigmine } \\
\text { galantamine }\end{array}$ & $\begin{array}{l}\leq 10^{10} \\
\leq 6^{8} \\
\leq 24^{9}\end{array}$ & & & & \\
\hline $\begin{array}{l}\text { Fuschillo } \\
\text { et al. [27] } \\
(2004)\end{array}$ & $\begin{array}{l}\text { donepezil } \\
\text { rivastigmine } \\
\text { galantamine }\end{array}$ & \multicolumn{2}{|c|}{$\begin{array}{r}6.1 \pm 2.2 \text { (baseline); } 8.5 \pm 2.3^{4} \\
5.2 \pm 2.4 \text { (baseline); } 7.4 \pm 2.5^{4} \\
14.8 \pm 2.1^{7}\end{array}$} & & & \\
\hline
\end{tabular}

$\mathrm{NR}=$ Not reported. ${ }^{*} \mathrm{p}<0.001$ in favour of donepezil.

${ }^{1}$ Percentage of patients who did not tolerate a minimum effective dose: $5 \mathrm{mg}$ for donepezil and $6 \mathrm{mg}$ for rivastigmine. ${ }^{2}$ Both treatments initiated at lowest marketed dose $(5 \mathrm{mg} /$ day for donepezil and $3 \mathrm{mg} /$ day for rivastigmine) and subjects were seen after 1 month. Dose titration was slow with minimal intervals of 1 month. In case of AEs, subjects were re-titrated to a maximum previously well-tolerated dose and no further dose escalation was undertaken. ${ }^{3}$ Patients were commenced on the smallest dose recommended and followed up after 4 weeks. If the drug was tolerated, dose was increased and an efficacy assessment carried out in 3-4 months, at which time an assessment was made whether to continue treatment, after consulting with patient, carers and considering cognitive test scores. ${ }^{4}$ Dose at 1 -year follow up. ${ }^{5}$ Nonsignificant difference between treatments: defined as 5/10 mg donepezil and 9-12 mg rivastigmine. ${ }^{6}$ Information only available for the overall period that a resident was on therapy. Dosage shown is the median daily dose for residents whose therapy ended during days 43-365. ${ }^{7}$ Donepezil initiated at $5 \mathrm{mg} /$ day and neurologist increased dose to $10 \mathrm{mg} /$ day in the following control visit (between 4 and 8 months) if subject tolerated the treatment with $5 \mathrm{mg} /$ day. ${ }^{8}$ Rivastigmine initiated at $3 \mathrm{mg} /$ day during the first month. Caregivers instructed to progressively increase it to 6 and $9 \mathrm{mg} /$ day during the following 2 months. ${ }^{9}$ Galantamine initiated at $8 \mathrm{mg} /$ day during the first month. Caregivers instructed to progressively increase it to 16 and $24 \mathrm{mg} /$ day during the following 2 months. ${ }^{10}$ Donepezil (5 mg/day for 4 weeks) followed by a maintenance dose $(10 \mathrm{mg})$; ${ }^{11}$ Rivastigmine $1.5 \mathrm{mg}$ b.i.d. for 4 weeks followed by $3 \mathrm{mg}$ b.i.d. for 4 weeks; clinicians had the option of increasing the dose to a maximum of $6 \mathrm{mg}$ b.i.d. in increments of $1.5 \mathrm{mg}$ b.i.d. every 4 weeks. ${ }^{12}$ Galantamine $4 \mathrm{mg}$ b.i.d. for 4 weeks followed by $8 \mathrm{mg}$ b.i.d. as a maintenance dose. ${ }^{13} 5 \mathrm{mg}$ for donepezil and 3-6 mg for rivastigmine. ${ }^{14} 10 \mathrm{mg}$ for donepezil and 9-12 $\mathrm{mg}$ for rivastigmine. 


\section{Discussion}

The aim of the present systematic review was to assess qualitatively the safety and tolerability of the ChEIs for the treatment of $\mathrm{AD}$ in a real-world setting using headto-head studies comparing ChEIs as the evidence base. The tolerability of a treatment is particularly important for a condition such as $\mathrm{AD}$, where patients being treated tend to be elderly and have significant medical co-morbidity and polypharmacy. Consequently, any treatmentrelated AEs can be clinically significant, and may result in treatment discontinuation.

Possible limitations of the dataset in the present review should be highlighted and include heterogeneity in study design (table 2), a small number of patients in some treatment arms [30, 34], limited data on the relationship between dosing regimen and the incidence of GI AEs [25] and the short treatment duration of some studies (e.g. 6 months in 2 of the prospective studies) [28,31]. It has been suggested that clinically relevant differences in a chronic condition such as AD can only be demonstrated after relatively long treatment durations [36]. However, shorterterm studies are valid for evaluating the benefits of treatments and report valuable information with regard to initial efficacy, tolerability and compliance. With regard to study design, between-study heterogeneity in 'real-world' studies is more likely to be encountered compared with RCTs, which have more standardised study design requirements. In the present review, studies were grouped on the basis of prospective or retrospective design. Heterogeneity is more apparent in the retrospective studies which differ more with regard to included subjects and healthcare setting compared with the prospective studies. However, despite this variability, a pattern of fewer total and GI AEs was still discernible in donepezil-treated subjects compared with rivastigmine and galantamine treatment in both prospective and retrospective studies.

The present review also has several strengths. The use of a comprehensive search strategy (electronic databases in addition to selected conference proceedings) maximised the likelihood of identifying all potentially relevant publications. Duplicate quality assessment of included studies reduced the potential for bias in this component of the review. Results were reported from studies reflecting the real-world conditions of care, ChEI dosing regimens and disease co-morbidity, which cannot be obtained from RCT-protocol-based studies. Therefore, subjects enrolled in the 'real-world' studies in the present review may be considered to be more representative of the general population of $\mathrm{AD}$ subjects treated in every- day clinical practice compared with participants in RCTs.

Indeed, the external validity and generalisability of many RCTs have been questioned [12] as a consequence of the fact that they may include highly selected study populations due to the enrolment of subjects meeting strict inclusion criteria. For example, several of the AD RCTs performed to date have excluded subjects with comorbidities (e.g. diabetes, asthma or COPD) [37-39] or those taking concomitant medications (e.g. antidepressants, sedatives or antihypertensive agents) $[40,41]$. In addition, several of the RCTs have employed an enforced titration schedule which dictates that dosages be escalated to certain levels at specified time intervals leading to a more rapid escalation than that recommended in the approved product labelling [39-44]. The recommended dose escalation schedules for the individual ChEIs are [45]:

- Donepezil: subjects initiated at $5 \mathrm{mg} /$ day for at least 1 month prior to an increase to $10 \mathrm{mg} /$ day.

- Rivastigmine: subjects initiated at $1.5 \mathrm{mg}$ twice daily. At 14-day intervals the dose may be increased by increments of $1.5 \mathrm{mg}$ twice daily up to a maximum dosage of $6 \mathrm{mg}$ twice daily.

- Galantamine: subjects initiated at $4 \mathrm{mg}$ twice daily for 4 weeks, after which time the dose can be increased to $8 \mathrm{mg}$ twice daily for at least a further 4 weeks. A further increase to a final maintenance dose of $12 \mathrm{mg}$ twice daily may be permitted.

Three of the six prospective studies included in the present review provided details of the dose titration regimen used $[27,28,34]$. The titration schedules used were not homogeneous between the ChEIs. For example, in the study by Lopez-Pousa et al. [28] the caregivers of subjects treated with rivastigmine or galantamine were instructed to progressively increase the treatment dose over a 2month period until the maximum tolerated dose was reached, compared with many donepezil-treated subjects who began on $5 \mathrm{mg} /$ day but did not have their treatment titrated up to $10 \mathrm{mg} /$ day by their neurologist until after the 6-month follow-up appointment.

One of the aims of the present review was to compare the incidence of AEs obtained in the real-world setting with those from the RCT setting. While the results are not directly comparable with those from RCTs due to the absence of an untreated cohort arm, results can be compared with data from the treatment arms of the RCTs. A number of previous systematic reviews have examined the efficacy and tolerability of ChEIs in the treatment of $\mathrm{AD}[8,20,46,47]$. These reviews have focused on data 
from RCTs only, with between 6 [47] and 43 RCTs [46] meeting the inclusion criteria of the various reviews. However, the majority of RCTs performed to date have been placebo controlled and there is a paucity of headto-head comparisons, with only 6 such RCTs included in these systematic reviews [15-17, 38, 48, 49]. The most frequently reported AEs in RCTs were GI in nature (nausea, vomiting, diarrhoea) [8], and this was confirmed in the present study. In the head-to-head RCTs, rates of treatment-emergent GI AEs were generally higher in the galantamine group compared with donepezil, and generally higher in the rivastigmine group compared with donepezil $[20,25]$. For example, the mean frequency for nausea was $11 \%$ for donepezil, $44 \%$ for rivastigmine and $24 \%$ for galantamine [25]. This finding is consistent with the current results from studies in a routine clinical setting (table 5) [23-25, 27, 31, 32].

The incidence of GI AEs reported in the present review was lower than that observed from the RCT data (table 5) [8, 20, 46, 47]. For example, whereas the incidence of nausea was reported to be $44 \%$ in rivastigminetreated subjects within RCTs [8], the highest reported incidence was $23.1 \%$ in a routine clinical setting [33]. This difference may result from a stricter monitoring of subjects enrolled in RCTs, a possible underreporting of AEs in the everyday clinical setting, or the higher titration speed adopted in the RCT setting. Research has shown that the incidence of AEs is directly related to the dose of ChEI administered $[32,50]$, with enforced titration schedules (e.g. escalation to $10 \mathrm{mg} /$ day donepezil after only 1 week at $5 \mathrm{mg}$ /day) increasing the likelihood of experiencing AEs [39]. Therefore, a slow and gradual increase in the dose of ChEI in the everyday clinical setting is an important factor for obtaining a balance between clinical efficacy and tolerability, thereby maximising any positive effects on cognitive function while minimising the incidence of AEs [23].

Non-GI AEs were reported by a small number of subjects in the majority of studies in the present review (tables 6,7$)$ and, in contrast to GI AEs, the incidence of such events were comparable with that observed in previous systematic reviews of RCTs $[8,46,51]$. One exception was weight loss which was reported in 15-20\% of ChEI-treated subjects in a single retrospective study [25] compared with $7-11 \%$ in the RCT setting [8]. This may be attributed to differences in the study populations: the retrospective study examined nursing home residents who are more likely to have advanced AD and co-morbid conditions associated with an increased susceptibility to weight loss compared with subjects enrolled in RCTs. A previous sys- tematic review of the RCT literature reported that between 3 and $7 \%$ of donepezil-treated subjects $(5-10 \mathrm{mg} /$ day) experienced insomnia [51]. The incidence of insomnia was not reported for rivastigmine- or galantaminetreated subjects. However, in the present review the incidence of insomnia was similar for all the ChEIs (5-7\%; table 7), and within the range reported from the RCT evidence [51].

Two studies reported that a significant number of subjects were treated with less than the minimal effective dose of ChEI (table 8) [25, 32]. For example, in the study by Hughes et al. [25], data on drug dosage for all 3 ChEIs indicated that approximately $50 \%$ of subjects were being treated with less than the clinically effective dose at 43 days after treatment initiation. Indeed, the daily treatment doses of ChEIs reported in the present analysis (table 8) were lower than those reported in the RCT literature [46]. Again, this may be a consequence of the more relaxed exclusion criteria in the present studies, leading to the inclusion of subjects with co-morbidities who are less able to tolerate higher treatment doses.

\section{Conclusion}

The body of evidence from studies conducted in an everyday clinical setting suggests that donepezil has a more advantageous tolerability profile compared with rivastigmine and galantamine, exemplified by fewer withdrawals due to AEs, a lower incidence of GI AEs, and more subjects achieving a maximum tolerated dose. The findings from the present review are clinically relevant, and are applicable to the day-to-day treatment of subjects with AD. Further well-designed head-to-head studies comparing the ChEIs are necessary to confirm these findings.

References

Dement Geriatr Cogn Disord 2009;28:389-403
Solfrizzi V, D’Introno A, Colacicco AM, Capurso C, Del Parigi A, Capurso S, Gadaleta A, Capurso A, Panza F: Dietary fatty acids intake: possible role in cognitive decline and dementia. Exp Gerontol 2005;40:257-270.

-2 Burns A, O’Brien J: Clinical practice with anti-dementia drugs: a consensus statement from British Association for Psychopharmacology. J Psychopharmacol 2006;20:732755.

3 Brookmeyer R, Gray S, Kawas C: Projections of Alzheimer's disease in the United States and the public health impact of delaying disease onset. Am J Public Health 1998;88: 1337-1342. 
4 House of Commons Committee of Public Accounts: Improving services and support for people with dementia: sixth report of session 2007-08. London, The Stationery Office, 2008.

5 King's College London and London School of Economics and Political Science: Dementia UK (Report to the Alzheimer's Society). London, Alzheimer's Society, 2007.

6 National Institute for Health and Clinical Excellence: Donepezil, galantamine, rivastigmine (review) and memantine for the treatment of Alzheimer's disease (amended): NICE technology appraisal guidance 111 (amended). London, National Health Service, 2007.

7 Medicines Management Team NHS Lothian: Drugs not recommended by the Scottish Medicines Consortium (SMC). 2008. www. ljf.scot.nhs.uk/smc_lists/smc_not_recommended_drugs.pdf.

8 Hansen RA, Gartlehner G, Webb AP, Morgan LC, Moore CG, Jonas DE: Efficacy and safety of donepezil, galantamine, and rivastigmine for the treatment of Alzheimer's disease: a systematic review and meta-analysis. Clin Interv Aging 2008;3:211-225.

$\checkmark 9$ Raina P, Santaguida P, Ismaila A, Patterson C, Cowan D, Levine M, Booker L, Oremus M: Effectiveness of cholinesterase inhibitors and memantine for treating dementia: evidence review for a clinical practice guideline. Ann Intern Med 2008;148:379-397.

-10 Kavirajan H, Schneider LS: Efficacy and adverse effects of cholinesterase inhibitors and memantine in vascular dementia: a metaanalysis of randomised controlled trials. Lancet Neurol 2007;6:782-792.

-11 Fortin M, Dionne J, Pinho G, Gignac J, Almirall J, Lapointe L: Randomized controlled trials: do they have external validity for patients with multiple comorbidities? Ann Fam Med 2006;4:104-108.

12 Rothwell PM: External validity of randomised controlled trials: 'to whom do the results of this trial apply?' Lancet 2005;365: 82-93.

$\checkmark 13$ Brodaty H, Woodward M, Boundy K, Barnes $\mathrm{N}$ : Naturalistic treatment of Alzheimer's disease with galantamine: 12-month follow-up from the nature study. CNS Drugs 2007;21: 335-336.

14 Gauthier S, Juby A, Morelli L, Rehel B, Schecter R: A large, naturalistic, community-based study of rivastigmine in mild-tomoderate AD: the extend study. Curr Med Res Opin 2006;22:2251-2265.

15 Wilkinson DG, Passmore AP, Bullock R, Hopker SW, Smith R, Potocnik FCV, Maud CM, Engelbrecht I, Hock C, Ieni JR, Bahra RS: A multinational, randomised, 12-week, comparative study of donepezil and rivastigmine in patients with mild to moderate Alzheimer's disease. Int J Clin Pract 2002;56: 441-446.
16 Wilcock G, Howe I, Coles H, Lilienfeld S, Truyen L, Zhu Y, Bullock R, Kershaw P, GAL-GBR-2 Study Group: A long-term comparison of galantamine and donepezil in the treatment of Alzheimer's disease. Drugs Aging 2003;20:777-789.

17 Bullock R, Touchon J, Bergman H, Gambina G, He Y, Rapatz G, Nagel J, Lane R: Rivastigmine and donepezil treatment in moderate to moderately-severe Alzheimer's disease over a 2-year period. Curr Med Res Opin 2005;21:1317-1327.

18 Harry RD, Zakzanis KK: A comparison of donepezil and galantamine in the treatment of cognitive symptoms of Alzheimer's disease: a meta-analysis. Hum 2005;20:183-187.

19 Kavirajan H, Schneider LS: Efficacy and adverse effects of cholinesterase inhibitors and memantine in vascular dementia: a metaanalysis of randomised controlled trials. Lancet Neurol 2007;6:782-792.

20 Takeda A, Loveman E, Clegg A, Kirby J, Picot J, Payne E, Green C: A systematic review of the clinical effectiveness of donepezil, rivastigmine and galantamine on cognition quality of life and adverse events in Alzheimer's disease. Int J Geriatr Psychiatry 2006; 21:17-28.

21 Wells G, Shea B, O'Connell D, Robertson J, Peterson J, Welch V, Losos M, Tugwell P: The Newcastle-Ottawa Scale (NOS) for assessing the quality of nonrandomized studies in meta-analysis.

22 The Cochrane Collaborative Review Group on HIV Infection and AIDS: Editorial policy: inclusion and appraisal of experimental and non-experimental (Observational) Studies.http://www.igh.org/Cochrane/pdfs/ EP_inclusionquality.pdf.

23 Turon-Estrada A, Lopez-Pousa S, GeladaBatlle E, Garre-Olmo J, Lozano-Gallego M, Hernandez-Ferrandiz M, Fajardo-Tibau C, Morante-Munoz V, Vilalta-Franch J: Tolerance and adverse events of treatment with acetylcholinesterase inhibitors in a clinical sample of patients with very slight and mild Alzheimer's disease over a six-month period. Rev Neurol 2003;36:421-424.

24 Sobow T, Kloszewska I: Cholinesterase inhibitors in the 'real world' setting: rivastigmine versus donepezil tolerability and effectiveness study. Arch Med Sci 2006;2:194198.

25 Hughes A, Musher J, Thomas SK, Beusterien KM, Strunk B, Arcona S: Gastrointestinal adverse events in a general population sample of nursing home residents taking cholinesterase inhibitors. Consult Pharm 2004;19: 713-720.

26 Mossello E, Tonon E, Caleri V, Tilli S, Cantini C, Cavallini MC, Bencini F, Mecacci R, Marini M, Bardelli F, Sarcone E, Razzi E, Biagini CA, Masotti G: Effectiveness and safety of cholinesterase inhibitors in elderly subjects with Alzheimer's disease: a 'real world' study. Arch Gerontol Geriatr Suppl 2004;9:297-307.
27 Fuschillo C, Ascoli E, Franzese G, Campana F, Cello C, Galdi M, La Pia S, Cetrangolo C: Alzheimer's disease and acetylcholinesterase inhibitor agents: a two-year longitudinal study. Arch Gerontol Geriatr Suppl 2004;9: 187-194.

28 López-Pousa S, Turon-Estrada A, GarreOlmo J, Pericot-Nierga I, Lozano-Gallego M, Vilalta-Franch M, Hernandez-Ferrandiz M, Morante-Munoz V, Isern-Vila A, GeladaBatlle E, Majo-Llopart J: Differential efficacy of treatment with acetylcholinesterase inhibitors in patients with mild and moderate Alzheimer's disease over a 6-month period. Dement Geriatr Cogn Disord 2005;19:189195.

29 De La Gastine B, Mosquet B, Coquerel A: Assessment of adverse effects of Alzheimer's disease medications: analysis of notifications to regional pharmacovigilance centers in northwest France. Revue de Geriatrie 2007;32:575-584

30 Lleshi E, Nicod M, Coutaz M, Morisod J: Study of the prescription efficiency and tolerance of acetylcholinesterase inhibitors in Alzheimer's disease. Med Hyg (Geneve) 2004;62:1849-1856.

31 Aguglia E, Onor ML, Saina M, Maso E: An open-label, comparative study of rivastigmine, donepezil and galantamine in a realworld setting. Curr Med Res Opin 2004;20: 1747-1752.

-32 Raschetti R, Maggini M, Sorrentino GC, Martini N, Caffari B, Vanacore N: A cohort study of effectiveness of acetylcholinesterase inhibitors in Alzheimer's disease. Eur J Clin Pharmacol 2005;61:361-368.

-33 Pakrasi S, Mukaetova-Ladinska EB, McKeith IG, O'Brien JT: Clinical predictors of response to acetyl cholinesterase inhibitors: experience from routine clinical use in Newcastle. Int J Geriatr Psychiatry 2003;18:879886.

34 Shua-Haim JR, Pass MD, Patel S, Patel S, Lee P, Patel P: A head to head study of donepezil, rivastigmine, and galantamine for the treatment of Alzheimer's disease: safety, tolerability, clinical and caregiver impressions after 9 months of treatment. Poster Int Conf Alzheimer's Dis, 2004.

35 Bianchetti A, Padovani A, Trabucchi M: Outcomes of Alzheimer's disease treatment: The Italian CRONOS project. Int J Geriatr Psychiatry 2003;18:87-88.

36 Bullock R, Truyen L: Not all head-to-head trials are created equal: results from an openlabel, short-term study seem inconsistent with previous donepezil literature. Int J Geriatr Psychiatry 2005;20:85-87.

-37 Brodaty H, Corey-Bloom J, Potocnik FCV, Truyen L, Gold M, Damaraju CRV: Galantamine prolonged-release formulation in the treatment of mild to moderate Alzheimer's disease. Dement Geriatr Cogn Disord 2005; 20:120-132. 
-38 Jones RW, Soininen H, Hager K, Aarsland D, Passmore P, Murthy A, Zhang R, Bahra R: A multinational, randomised, 12 -week study comparing the effects of donepezil and galantamine in patients with mild to moderate Alzheimer's disease. Int J Geriatr Psychiatry 2004;19:58-67.

-39 Rogers SL, Doody RS, Mohs RC, Friedhoff LT: Donepezil improves cognition and global function in Alzheimer disease: a 15-week, double-blind, placebo-controlled study. Donepezil Study Group. Arch Intern Med 1998;158:1021-1031.

-40 Rogers SL, Farlow MR, Doody RS, Mohs R, Friedhoff LT: A 24-week, double-blind, placebo-controlled trial of donepezil in patients with Alzheimer's disease. Donepezil Study Group. Neurology 1998;50:136-145.

-41 Wilkinson D, Murray J: Galantamine: A randomized, double-blind, dose comparison in patients with Alzheimer's disease. Int J Geriatr Psychiatry 2001;16:852-857.

42 Wilcock GK, Lilienfeld S, Gaens E: Efficacy and safety of galantamine in patients with mild to moderate Alzheimer's disease: multicentre randomised controlled trial. Galantamine International-1 Study Group. BMJ 2000;321:1445-1449.
43 Rosler M, Anand R, Cicin-Sain A, Gauthier S, Agid Y, Dal-Bianco P, Stahelin HB, Hartman R, Gharabawi M: Efficacy and safety of rivastigmine in patients with Alzheimer's disease: international randomised controlled trial. BMJ 1999;318:633-638.

44 Rockwood K, Mintzer J, Truyen L, Wessel T, Wilkinson D: Effects of a flexible galantamine dose in Alzheimer's disease: a randomised, controlled trial. J Neurol Neurosurg Psychiatry 2001;71:589-595.

45 Joint Formulary Committee: British National Formulary, ed 57. London, British Medical Association and Royal Pharmaceutical Society of Great Britain, 2009.

46 Raina P, Santaguida P, Ismaila A, Patterson C, Cowan D, Levine M, Booker L, Oremus M: Effectiveness of cholinesterase inhibitors and memantine for treating dementia: evidence review for a clinical practice guideline. Ann Intern Med 2008;148:379-397.
7 Kavirajan H, Schneider LS: Efficacy and adverse effects of cholinesterase inhibitors and memantine in vascular dementia: a metaanalysis of randomised controlled trials. Lancet Neurol 2007;6:782-792.

48 Ancoli-Israel S, Amatniek J, Ascher S, Sadik K, Ramaswamy K: Effects of galantamine versus donepezil on sleep in patients with mild to moderate Alzheimer disease and their caregivers: a double-blind, head-tohead, randomized pilot study. Alzheimer Dis Assoc Disord 2005;19:240-245.

49 Fuschillo C, La Pia S, Campana F, Pinto A, De Simone L: Cognitive deficits in Alzheimer's disease: treatment with acetylcholinesterase inhibitor agents. Arch Gerontol Geriatr Suppl 2001;7:151-158.

50 Tariot PN, Solomon PR, Morris JC, Kershaw P, Lilienfeld S, Ding C: A 5-month, randomized, placebo-controlled trial of galantamine in AD: the Galantamine USA-10 Study Group. Neurology 2000;54:2269-2276.

-51 Kaduszkiewicz H, Zimmermann T, BeckBornholdt HP, Van Bussche HD: Cholinesterase inhibitors for patients with Alzheimer's disease: systematic review of randomised clinical trials. BMJ 2005;331:321-323. 